Amino Acids. 2017 Jun;49(6):1053-1067. doi: 10.1007/s00726-017-2402-9.

Epub 2017 Mar 17.

DOI: $10.1007 / \mathrm{s} 00726-017-2402-9$

PMID: 28314993

Comparative analysis of internalisation, haemolytic, cytotoxic and antibacterial effect of membrane-active cationic peptides: aspects of experimental setup.

Horváti K, Bacsa B, Mlinkó T, Szabó N, Hudecz F, Zsila F, Bősze S. 


\title{
Comparative analysis of internalisation, haemolytic, cytotoxic and antibacterial effect of membrane active cationic peptides: aspects of experimental setup
}

\author{
Kata Horváti ${ }^{\mathrm{a}}$, Bernadett Bacsa ${ }^{\mathrm{a}}$, Tamás Mlinkób ${ }^{\mathrm{b}}$ Nóra Szabób ${ }^{\mathrm{b}}$, Ferenc Hudecz $^{\mathrm{a}, \mathrm{c}}$, \\ Ferenc Zsila ${ }^{\mathrm{d}}$ and Szilvia Bősze ${ }^{\mathrm{a}} *$
}

${ }^{a}$ MTA-ELTE Research Group of Peptide Chemistry, Hungarian Academy of Sciences Budapest, Hungary;

${ }^{\mathrm{b}}$ Laboratory of Bacteriology, Korányi National Institute for Tuberculosis and Respiratory Medicine, Budapest, Hungary;

${ }^{c}$ Department of Organic Chemistry, Eötvös Loránd University, Budapest, Hungary;

${ }^{\mathrm{d} B i o m o l e c u l a r ~ S e l f-A s s e m b l y ~ G r o u p, ~ I n s t i t u t e ~ o f ~ M a t e r i a l s ~ a n d ~ E n v i r o n m e n t a l ~ C h e m i s t r y, ~}$ Research Centre for Natural Sciences, Hungarian Academy of Sciences, Budapest, Hungary.

* Corresponding author. Dr. Szilvia Bősze, PhD, MTA-ELTE Research Group of Peptide Chemistry, Pázmány P. stny. 1/A, Budapest, Hungary, 1117. Tel: +36-1-372-2500 ext. 1736, fax: +36-1-372-2620, e-mail: szilvia.bosze@gmail.com

\section{ACKNOWLEDGEMENTS}

This work was supported by the Hungarian Research Fund (115431 and 104275) and by the János Bolyai Research Scholarship of the Hungarian Academy of Sciences. The authors thank to Dr. Hedvig Medzihradszky-Schweiger for the amino acid analysis and to Mr. Sándor Dávid for the antimycobacterial testing. 


\begin{abstract}
Cationic peptides proved fundamental importance as pharmaceutical agents and/or drug-carrier moieties functioning in cellular processes. The comparison of the in vitro activity of these peptides is an experimental challenge and a combination of different methods, such as cytotoxicity, internalisation rate, haemolytic and antibacterial effect, is necessary. At the same time several issues need to be addressed as the assay conditions have a great influence on the measured biological effects and the experimental setup need to be optimised. Therefore, critical comparison of results from different assays using representative examples of cell penetrating and antimicrobial peptides was performed and optimal test conditions were suggested. Our main goal was to identify carrier peptides for drug delivery systems of antimicrobial drug candidates. Based on the results of internalisation, haemolytic, cytotoxic and antibacterial activity assays, a classification of cationic peptides is advocated. We found eight promising carrier peptides with good penetration ability of which Penetratin, Tat, Buforin and Dhvar4 peptides showed low adverse haemolytic effect. Penetratin, Transportan, Dhvar4 and the hybrid CM15 peptide had the most potent antibacterial activity on Streptococcus pneumoniae (MIC lower than $1.2 \mu \mathrm{M}$ ) and Transportan was effective against Mycobacterium tuberculosis as well. The most selective peptide was the Penetratin, where the effective antimicrobial concentration on pneumococcus was more than 250-times lower than the $\mathrm{HC}_{50}$ value. Therefore, these peptides and their analogues will be further investigated as drug delivery systems for antimicrobial agents.
\end{abstract}

\title{
KEYWORDS
}

Cationic peptides; cell penetrating peptide; antimicrobial peptide; antibacterial drug carrier; haemolysis; tuberculosis 


\section{INTRODUCTION}

In the design and development of new antimicrobial drug candidates, delivery to target site is one of the major consideration. However, several libraries of synthetic compounds providing activity against a vast spectrum of pathogens have been discovered so far, the general inability to penetrate the target cells seems to be the main obstacles, especially in the case of diseases that are caused by intracellular bacteria (Brown and Wright 2016).

The cellular uptake rate and the bioavailability of drug compounds can be enhanced by covalent attachment to appropriate targeting or carrier peptides. Cationic oligopeptides, including cell penetrating peptides (CPP) and certain antimicrobial peptides (AMP) have the ability to cross the lipid membrane and to access intracellular targets. Several cationic oligopeptides entered clinical trials (Marr et al. 2006; Yeung et al. 2011). However, lack of cell specificity and extensive cytotoxicity of CPPs still need to be addressed. To improve the therapeutic effect of these peptides, intracellular trafficking and antimicrobial activity with low cytotoxicity toward human host cells is needed. For the calculation of the in vitro selectivity the haemolytic activity toward human red blood cells (RBC) is often used for the comparison to the antimicrobial activity (Chen et al. 2005).

\subsection{Experimental Conditions of In Vitro Assays}

To determine the in vitro selectivity of membrane active cationic peptides many types of biological assays are described in the literature. Previous studies have warned that the absence of haemolysis or high $\mathrm{HC}_{50}$ values in certain media (i.e. PBS) can give untrue results, when the selectivity index is calculated (Saberwal and Nagaraj 1994). Even in the case of the bee venom Melittin, haemolytic activity can be inhibited if the phosphate concentration is raised (Helmerhorst et al. 1999; Portlock et al. 1990). In general, the membrane activity of many cationic peptides is strongly dependent on the ionic strength and salt content of the used media (Helmerhorst et al. 1999; Herbel and Wink 2016). Raghuraman and colleagues studied the effect of ionic strength on the dynamics and aggregation behaviour of Melittin and they showed, that the peptide undergoes a structural transition from a random coil monomer to an $\alpha$-helical tetramer at high ionic strength (Raghuraman and Chattopadhyay 2006; Raghuraman et al. 2006).

The most significant differences in the test conditions can be found in the haemolytic assays of peptides. Important variants are as follows: (i) concentration of RBC $(0.5 \% \mathrm{v} / \mathrm{v}$ (Hollmann et 
al. 2016), 1\% (Kobayashi et al. 2000), 2\% (Yang et al. 2013), 4\% (Lee and Lee 2008; Song et al. 2005), 20\% (Chongsiriwatana et al. 2008), $2 \times 10^{6}$ cells $/ \mathrm{mL}$ (Li et al. 2005) or $2.5 \times 10^{8}$ cells/mL (Dathe et al. 2001; Dathe et al. 1996), $1.2 \times 10^{9}$ cells/mL (Zeitler et al. 2013) etc.); (ii) incubation media (PBS (Chongsiriwatana et al. 2008; Dennison and Phoenix 2014; Hollmann et al. 2016; Lee and Lee 2008; Song et al. 2005), Tris (Dathe et al. 2001; Dathe et al. 1996; Zeitler et al. 2013), RPMI-1640 or HEPES buffer (Li et al. 2005), 0.9\% NaCl or normal saline (Wu et al. 2014), etc.); (iii) incubation time (30 min (Hollmann et al. 2016; Wu et al. 2014), 1 hour (Chongsiriwatana et al. 2008; Dennison and Phoenix 2014; Yang et al. 2013), 4 hrs (Li et al. 2005) or 18-24 hrs (Mojsoska et al. 2015)); (iii) used positive control (0.1\% Triton-X (Dennison and Phoenix 2014; Lee and Lee 2008; Song et al. 2005), 1\% Triton-X (Mojsoska et al. 2015), 10\% Triton-X (Wu et al. 2014), distilled water (Hollmann et al. 2016; Yang et al. 2013), $2 \%$ SDS (Zeitler et al. 2013), 0.05\% saponin (Davanco et al. 2014). There are differences even in the used wavelength at which the optical density of released haemoglobin is determined ( $\lambda=350 \mathrm{~nm}$ (Chongsiriwatana et al. 2008), 405-415 nm (Kaushik et al. 2012; Lee and Lee 2008; Song et al. 2005; Zeitler et al. 2013) , 540-550 nm (Davanco et al. 2014; Hollmann et al. 2016; Mojsoska et al. 2015; Yang et al. 2013) or $570 \mathrm{~nm}$ (Dennison and Phoenix 2014; Wu et al. 2014)).

Because of the different test conditions, it is questionable whether the results of the haemolytic assays can be properly compared to the antimicrobial activity and/or cytotoxicity that are usually performed in lower ionic strength media or broths (RPMI, HEPES, DMEM, Bouillon, etc.). Therefore we have investigated in the comparative analysis of haemolytic activity, cytotoxicity, cellular uptake and antimicrobial activity of cationic oligopeptides with the aim to clarify the role of experimental conditions such as the cell type, concentration of cells, used media, incubation time, anticoagulant and counter-ion, etc.

\subsection{Peptide Selection}

In this project, well studied cationic oligopeptides which can be considered as representative CPPs and AMPs, were chosen for critical analysis. Our goal was to identify peptides as promising antibacterial drug carriers with potent penetrating ability, antibacterial effect and suitable selectivity. Criteria of the peptide selection were the following: size (lower than 25 amino acids); cationic character; synthetic considerations, such as bearing suitable conjugation site; literature data on membrane activity (e.g. cell penetration and/or antibacterial effect). 
In many cases, however, the exact mechanism of bacterial killing of AMPs is not known; these evolutionarily conserved peptides can permeabilise the phospholipid membrane and provoke a broad spectrum of antimicrobial activity against bacteria, viruses, and fungi (Reddy et al. 2004; Yeaman and Yount 2003). Many antimicrobial peptides were isolated from amphibians, such as Magainin (Zasloff 1987) and Buforin (Park et al. 1996). Granulysin, a 9 kDa protein found in granules of cytotoxic T lymphocytes and natural killer cells, lyses a variety of tumour and bacterial cells in vitro, and directly kill Mycobacterium tuberculosis (Stenger et al. 1998). GranF2, a 23-mer peptide synthetic derivative, represents a helix-loop-helix region, which is postulated to be the membrane-docking part of Granulysin protein (Andreu et al. 1999). Histatins are salivary histidine-rich cationic peptides found in human parotid secretion. Synthetic derivatives, including Dhvar4, were studied on the ability to adopt helical conformation which is considered to be the key feature to act as membrane-active antimicrobial peptides (Helmerhorst et al. 1997). Crot(1-9,38-42) peptide is representing the $N$ - and $C$ terminus of Crotamine, a toxin found in the venom of rattlesnake (Andreu et al. 1992). Recently, chimera peptides were developed to improve the biological activity: CM15 is a linear, hybrid AMP composed of Cecropin A (1-7) and Melittin (2-9) (Radis-Baptista et al. 2008). The major toxin found in bee venom is Melittin, a linear 26-residue peptide, which displays strong lytic activity against bacteria and human cells (Habermann 1972), and it is often used as a positive control in haemolytic assays.

Cell penetrating peptides could have a great pharmaceutical potential as in vitro and in vivo delivery vectors for a wide range of bioactive cargos. CPPs are of different sizes, amino acid sequences, and charges but all published CPPs have the ability to translocate the plasma membrane and facilitate the delivery to the cytoplasm (El-Andaloussi et al. 2005; Hudecz et al. 2005; Morris et al. 2008; Vives et al. 2008). During the last two decades several CPPs were described. Tat (transactivator of transcription) and Penetratin, the two most studied CPPs, were derived from the sequence of HIV transactivator protein (Green and Loewenstein 1988) and the third helix of the homeodomain of Drosophila Antennapedia protein (Derossi et al. 1994). Transportan is a hybrid peptide, constructed from a 6-residue sequence of the neuropeptide Galanin (GWTLNSAGYLLGPHAVGNHRSFSDKNGLTS) with a peptide toxin from wasp venom (mastoparan, INLKALAALAKKIL) connected via a lysine (Langel et al. 1996).

Tuftsin is a receptor binding peptide produced by the enzymatic cleavage of the Fc-domain of the heavy chain of immunoglobulin G. Based on the canine tuftsin sequence, $[\text { TKPKG }]_{4}(\mathrm{OT} 20)$ 
peptide was developed in our laboratory (Bai et al. 2008; Horvati et al. 2012; Mezo et al. 2004). OT20 peptide, a tetramer derivative of tuftsin, represents comparable chain length (20-mer), net charge (9+) and hydrophilicity therefore it was used as negative control in this study.

\section{MATERIALS AND METHODS}

\section{Materials}

$N, N$ '-diisopropylcarbodiimide (DIC), triisopropylsilane (TIS) and Amberlit IRA-400 anionexchange resin were purchased from Fluka. The amino acid derivatives were obtained from Reanal or from IRIS Biotech. 1-hydroxybenzotriazole (HOBt) and trifluoroacetic acid (TFA) was also from IRIS Biotech. Fmoc-Rink Amide MBHA resin was purchased from NovaBiochem. Acetonitrile and dimethyl sulfoxide (DMSO) were from Merck. N,Ndimethylformamide (DMF) and dichloromethane (DCM) were from Reanal. Chromatographically purified bovine serum albumin (BSA), 5(6)-carboxyfluorescein (Cf) and 1,8-diazabicyclo[5.4.0]undec-7-ene (DBU) were obtained from Sigma-Aldrich.

For the in vitro assays RPMI-1640 medium, Dulbecco's Modified Eagle's Medium (DMEM), fetal calf serum (FCS), nonessential amino acids, 3-(4,5-dimethyltiazol-2-yl)-2,5-diphenyl tetrazolium bromide (MTT), sodium dodecyl sulfate (SDS), Löwenstein-Jensen medium base were obtained from Sigma-Aldrich. Sula medium, PBS buffer (10 mM sodium phosphate in $150 \mathrm{mM} \mathrm{NaCl}, \mathrm{pH}$ 7.4), Tris buffer (0.1 M tris(hydroxymethyl)aminomethane, $\mathrm{pH}$ 7.4, adjusted with $\mathrm{HCl}$ ), and HPMI buffer ( $9 \mathrm{mM}$ glucose, $10 \mathrm{mM} \mathrm{NaHCO}_{3}, 119 \mathrm{mM} \mathrm{NaCl}, 9 \mathrm{mM}$ HEPES, $5 \mathrm{mM} \mathrm{KCl}, 0.85 \mathrm{mM} \mathrm{MgCl}_{2}, 0.053 \mathrm{mM} \mathrm{CaCl}_{2}, 5 \mathrm{mM} \mathrm{Na}_{2} \mathrm{HPO}_{4} \times 2 \mathrm{H}_{2} \mathrm{O}, \mathrm{pH}$ 7.4) were prepared in our laboratory using components obtained from Sigma-Aldrich. $0.9 \% \mathrm{NaCl}$ was a Fresenius infusion solution.

\subsection{Peptide Synthesis and Purification}

Peptides were produced on $100 \mathrm{mg}$ Fmoc-Rink Amide MBHA (capacity $=0.67 \mathrm{mmol} / \mathrm{g}$ ) resin in an automated peptide synthesizer (Syro-I, Biotage) using standard Fmoc/t'Bu strategy with DIC/HOBt coupling reagents. Peptides were cleaved from the resin with TFA/ $\mathrm{H}_{2} \mathrm{O} / \mathrm{TIS}(9.5$ : $2.5: 2.5 \mathrm{v} / \mathrm{v}$ ) mixture ( $2 \mathrm{hrs}, \mathrm{RT})$. After filtration the compounds were precipitated in cold diethyl ether, centrifuged (4000 rpm, $5 \mathrm{~min}$ ) and freeze-dried from water. Crude products were purified by RP-HPLC on a semipreparative C-18 Phenomenex Jupiter column $(250 \times 10 \mathrm{~mm})$ 
using gradient elution, consisted of $0.1 \%$ TFA in water (eluent A) and $0.1 \%$ TFA in acetonitrile/water $=80 / 20(\mathrm{v} / \mathrm{v})($ eluent $\mathrm{B})$.

For the cellular uptake studies $\mathrm{N}$-terminus of the peptides were labelled with 5(6)carboxyfluorescein (Cf) using DIC/HOBt coupling method. Cleavage, work-up and purification of Cf-peptides were performed in the same way as mentioned above.

\subsection{Peptide Characterization}

Purified peptides were analysed by RP-HPLC on an analytical C-18 Eurospher-100 $(5 \mu \mathrm{m}$, $250 \times 4 \mathrm{~mm}$ ) column using gradient elution with the above mentioned eluent A and B (flow rate was $1 \mathrm{~mL} / \mathrm{min}$, UV detection at $\lambda=220 \mathrm{~nm}$ ).

Molecular mass of peptides was determined by using a Bruker Esquire 3000+ ESI mass spectrometer. Peptide samples were dissolved in a mixture of acetonitrile/water $=1 / 1(\mathrm{v} / \mathrm{v})$ containing $0.1 \%$ acetic acid and introduced by a syringe pump with a flow rate of $10 \mu \mathrm{L} / \mathrm{min}$.

\subsubsection{Determination of Peptide Content by Amino Acid Analysis}

The peptide content was determined by amino acid analysis using a Sykam Amino Acid S433H analyser equipped with an ion-exchange separation column and postcolumn derivatization. Prior to analysis, samples were hydrolysed with $6 \mathrm{M} \mathrm{HCl}$ in sealed and evacuated tubes at $110^{\circ} \mathrm{C}$ for $24 \mathrm{~h}$. For post-column derivatization the ninhydrin-method was used.

\subsubsection{Counter-ion Replacement and the Determination of Fluorine Content}

Acetate-exchange of the purified peptides was performed using Amberlit IRA-400 (20-50 mesh, $\mathrm{Cl}^{-}$form) anion-exchange resin. First the resin was washed with water, three times with $0.2 \mathrm{M} \mathrm{NaOH}$, washed with water, and treated with $20 \mathrm{v} / \mathrm{v} \%$ acetic acid. After washing with water, $2 \mathrm{~g}$ resin was mixed with the peptide solution $(26.5 \mathrm{mg} / 4 \mathrm{ml}$ of water). The peptideresin suspension was stirred for $1 \mathrm{~h}$, then filtered and washed with $20 \mathrm{v} / \mathrm{v} \%$ acetic acid and water. After freeze-drying, peptides were analysed by analytical RP-HPLC, ESI MS and amino acid analysis. To calculate the anion-exchange rate, the Fluorine content of the peptides was determined by using modified Schöniger method (Rogers and Yasuda 1959). The exchange rate was calculated by dividing the percentage of the Fluorine content of acetate-exchanged peptide by the percentage of the Fluorine content of the original peptide. 


\subsubsection{Circular dichroism (CD) spectroscopic measurements and secondary structure estimation}

Peptide samples were dissolved in deionized water and in $10 \mathrm{mM}, \mathrm{pH} 7.3$ potassium phosphate buffer (0.05 M Na2 $\left.\mathrm{SO}_{4}\right)$. Far-UV CD curves were acquired on a JASCO J-715 spectropolarimeter at $25 \pm 0.2{ }^{\circ} \mathrm{C}$ in a $0.1 \mathrm{~cm}$ path-length rectangular quartz cuvette (Hellma, USA). Temperature control was provided by a Peltier thermostat. The CD data were monitored in continuous scanning mode between 185 and $260 \mathrm{~nm}$ at a rate of $50 \mathrm{~nm} / \mathrm{min}$, with a step size of $0.1 \mathrm{~nm}$, response time of $2 \mathrm{sec}$, three accumulations, $2 \mathrm{~nm}$ bandwidth. The CD curves were corrected by spectral contribution of blank water or buffer solution.

$\mathrm{CD}$ spectra were plotted in mean residue molar $\mathrm{CD}$ units $(\Delta \varepsilon /$ residue) calculated by the following equation:

$$
\Delta \varepsilon=\Theta /(32982 \mathrm{cl})
$$

where $\Theta$ is the measured ellipticity as a function of wavelength $(\mathrm{nm}), c$ is the molar concentration of the peptide, and $l$ is the optical path length $(\mathrm{cm})$.

The secondary structure content of CM15 was estimated from the CD spectra using the MS Excel version of the PEPFIT program developed originally by Reed and Reed (Amon et al. 2008; Reed and Reed 1997). It calculates the percentage of secondary contents by fitting experimental data to reference secondary structure spectra. The best fit is defined by the $\mathrm{R}^{2}$ value, where an $\mathrm{R}^{2}=1$ corresponds to a perfect fit. Before secondary structure analysis, the $\mathrm{CD}$ spectra were smoothed with a convolution width of 17 using the Means-Movement method (JASCO Spectra Analysis software, version 1.53.00).

\subsection{Haemolytic Activity Assay}

Peripheral blood from healthy volunteers was collected in vacuum tubes containing heparin (Liheparin LH, VenoSafe) as anticoagulant. Tubes were centrifuged (1000 rpm, $5 \mathrm{~min}$ ) and the pellet was washed 3 times with RPMI-1640 (culturing media without phenol red). To the pellet RPMI media was added to yield a final $4,1,0.25$ or $0.0625 \mathrm{v} / \mathrm{v} \% \mathrm{RBC}$ suspension. Peptides were dissolved in the same media and three-fold serial dilution series were prepared (final concentration: $0.1-200 \mu \mathrm{M})$. RBC suspension (100 $\mu \mathrm{L} /$ well $)$ were placed into a 96-well cell culture plate and mixed with $100 \mu \mathrm{L}$ peptide solution. The plates were incubated for $4 \mathrm{hrs}$ at $37^{\circ} \mathrm{C}$. After centrifugation $(1500 \mathrm{rpm}, 5 \mathrm{~min}), 100 \mu \mathrm{L}$ of the supernatant was transferred to a flat-bottom microtiter plate and absorbance was measured at $414 \mathrm{~nm}$ using an ELISA plate 
reader (iEMS Reader, Labsystems). The percentage haemolysis was compared to $0.1 \%$ Triton$\mathrm{X}$ treated $\mathrm{RBC}$ and the concentration of peptide at which $50 \%$ haemolysis ( $\mathrm{HC}_{50}$ value) was determined.

To study the time dependence of haemolysis, RBCs were incubated for $30 \mathrm{~min}$ or $4 \mathrm{hrs}$ or 24 hrs with $\mathrm{CM} 15$ peptide solution at $37^{\circ} \mathrm{C}$ using the same conditions as described above. To compare the effect of different anticoagulants on the haemolysis evoked by CM15 peptide, three types of vacuum tubes were used: heparin (Li-heparin LH, VenoSafe), EDTA (K $\mathrm{K}_{3}$-EDTA, VenoSafe), citrate (Na3-citrate 9NC, VenoSafe). To determine the effect of the addition of stabilizer, BSA was added to the stock solution of the CM15 peptide at $5 \mathrm{mg} / \mathrm{mL}(0.5 \%)$ concentration. The influence of different buffers was tested using either PBS, TRIS buffers, Bouillon broth, DMEM, RPMI (without phenol red) media or Fresenius $0.9 \% \mathrm{NaCl}$ infusion solution. Always the same media was used for washing, culturing the erythrocytes and for dissolving the peptide samples.

\subsection{Cell Culturing, Cytotoxicity Assay and Cell Morphology}

Peripheral blood mononuclear cells (PBMC) were prepared from peripheral blood of healthy volunteers (purchased from Hungarian National Blood Transfusion Service, HNBTS) using Ficoll-Hypaque density gradient centrifugation method. PBMC were cultured in complete medium prepared from RPMI-1640 supplemented with 10\% FCS, 2 mM L-glutamine and 160 $\mu \mathrm{g} / \mathrm{mL}$ gentamycin at $37^{\circ} \mathrm{C}$ in $5 \% \mathrm{CO}_{2}$ atmosphere. Twenty-four hours prior to treatment, PBMC cells were plated into a 96-well round bottom plate $(250.000$ cell/100 $\mu \mathrm{L}$ complete medium).

MonoMac6 human monocytic cell line (DSMZ no.: ACC 124) and HepG2 human hepatocellular liver carcinoma cell line (ATCC HB-8065) were maintained under conditions described above. For cytotoxicity assay, cells were distributed on a 96-well flat bottom tissue culture plate (5000 cell/100 $\mu \mathrm{L}$ complete RPMI-1640 medium).

SH-SY5Y human neuroblastoma cell line (ATCC CRL-2266) was cultured in DMEM medium containing 10\% FCS, $2 \mathrm{mM}$ L-glutamine, $160 \mu \mathrm{g} / \mathrm{mL}$ gentamycin, $1 \mathrm{mM}$ pyruvate and $1 \%$ nonessential amino acids. SH-SY5Y cells (10.000 cell/100 $\mu \mathrm{L}$ complete DMEM medium) were plated into a 96-well flat bottom tissue culture plate. 
Prior to treatment, cells were washed with serum-free RPMI-1640 (PBMC, MonoMac6, HepG2) or DMEM (SH-SY5Y) medium. Peptides to be tested were dissolved in serum-free medium and added to the cells to achieve $0.15 \mu \mathrm{M}-300 \mu \mathrm{M}$ final concentration. Cells were incubated with the peptides for $4 \mathrm{hrs}$, then the cell viability was tested using MTT assay (Liu et al. 1997; Mosmann 1983; Slater et al. 1963). Briefly, $45 \mu$ L MTT solutions were added to each well $(2 \mathrm{mg} / \mathrm{ml}$, solved in serum-free medium). Following $4 \mathrm{hrs}$ of incubation, plates were centrifuged at $2000 \mathrm{rpm}$ for 5 minutes, and the supernatant was carefully aspirated with a G30 needle. The precipitated purple crystals were dissolved in $100 \mu \mathrm{L}$ DMSO, and after 10 minutes agitation, the absorbance was determined at $\lambda=540 \mathrm{~nm}$ and $620 \mathrm{~nm}$ using ELISA plate reader (iEMS Reader, Labsystems). Cytotoxicity, expressed in percentage as the function of peptide concentration was represented graphically and $\mathrm{IC}_{50}$ values were determined.

To visualize cell morphology after peptide treatment, microscopic images of MonoMac6 cells were captured. MonoMac6 cells were plated in a 96-well flat bottom tissue culture plate (5000 cell/100 $\mu \mathrm{L}$ RPMI-1640 medium without phenol red), then treated with the peptides for $4 \mathrm{hrs}$ at 1,10 and $100 \mu \mathrm{M}$ final concentration. Microscopic images of the adherent cells were captured using an Olympus CKX41 microscope.

\subsection{Cellular Uptake Studies by Flow Cytometry}

The measurement of cell penetration of the compounds was evaluated on MonoMac6 human monocytic cell line by using a BD LSR II flow cytometer (BD Biosciences, San Jose, CA, USA) with $488 \mathrm{~nm}$ (Coherent Sapphire, $22 \mathrm{~mW}$ ) laser. Cells were harvested in the logarithmic phase of growth and plated on a 24 -well tissue culture plate $\left(10^{5}\right.$ cells $/ 1 \mathrm{~mL}$ medium/well $) 24$ hours prior to the experiment. Cf-labelled peptides were dissolved in serum free RPMI medium and added to the cells at 20,10 and $5 \mu \mathrm{M}$ final concentrations. Cells were incubated with compounds for $2 \mathrm{hrs}\left(37{ }^{\circ} \mathrm{C}, 5 \% \mathrm{CO}_{2}\right.$ atmosphere). After centrifugation (1000 rpm, $5 \mathrm{~min}$ ) and washing with RPMI medium, supernatant was removed and $100 \mu \mathrm{L} 1 \mathrm{mM}$ trypsin was added to the cells. After 5 min incubation at $37{ }^{\circ} \mathrm{C} 0.8 \mathrm{~mL} \mathrm{10 \%} \mathrm{FCS/HPMI} \mathrm{medium} \mathrm{was} \mathrm{added} \mathrm{than} \mathrm{cells} \mathrm{were}$ washed and re-suspended in $0.5 \mathrm{~mL}$ HPMI. The cell viability was assessed using $10 \mu \mathrm{g} / \mathrm{mL}$ propidium iodide (PI) solution (for the gating strategy see Supporting Information FIGURE S1). The intracellular fluorescence intensity of the cells was measured on channel PE LP550 (emission at $\lambda=550 \mathrm{~nm}$ ) and data were analysed with FACSDiva 5.0 software. All 
measurements were performed in triplicates. Parallel with flow cytometry measurements microscopic image of the cells were captured with an Olympus CKX41 microscope.

\subsection{In Vitro Antibacterial Activity Assay}

In vitro antibacterial activity of the compounds was determined against Streptococcus pneumoniae (ATCC 49619) by serial dilution method in Bouillon medium, which was prepared in-house. Compounds were added to the medium as $10 \mu \mathrm{L}$ DMSO solutions in duplicates (range of final concentrations was between 1.2 and $300 \mu \mathrm{M}$ ). Each tube was inoculated with 0.5 Mcfarland bacteria and the minimal Inhibitory concentration (MIC) was determined after incubation at $37{ }^{\circ} \mathrm{C}$ for $24 \mathrm{hrs}$. MIC was the lowest concentration of a compound at which no visible growth of the bacteria occurred.

Antitubercular effect of the compounds was also tested on Mycobacterium tuberculosis $\mathrm{H}_{37} \mathrm{Rv}$ (ATCC 27294) in Sula semisynthetic medium (prepared in-house) (Sula 1963; Sula and Sundaresan 1963; Vinsova et al. 2006) using previously described method (Baranyai et al. 2015; Horvati et al. 2015). Compounds were dissolved in DMSO and added to the medium at ten various concentrations $(c=0.5-500 \mu \mathrm{M})$. MIC value was determined after incubation at $37{ }^{\circ} \mathrm{C}$ for 28 days. In order to confirm the growth inhibition colony forming unit (CFU) was determined by subculturing from the Sula medium onto drug-free Löwensten-Jensen solid medium. Samples were further incubated for 28 days. Experiments were repeated at least two times.

Selectivity indices were calculated from the concentration value where $50 \%$ of human RBCs were lysed $\left(\mathrm{HC}_{50}\right)$ by the peptides divided by the minimal inhibitory concentration (MIC) determined against Streptococcus pneumoniae. Both in vitro measurements were performed in Bouillon broth using 24 hrs incubation time.

\subsection{Statistical Analysis}

In vitro tests were performed in triplicates and the results were expressed as mean \pm Std. deviation. For the evaluation of haemolysis and cytotoxicity and for the determination of $\mathrm{HC}_{50}$ and $\mathrm{IC}_{50}$ values of the peptides dose-response curves were plotted with non-linear regression analysis using GraphPad Prism 5.0 software. The effects of different experimental conditions (incubation time, media, percentage of RBC, anticoagulant and counter ion) were analysed by one-way ANOVA test by using GraphPad Prism 5.0 software. If means were significantly 
different $(\mathrm{P}<0.05)$, than ANOVA test was followed by a t-test (unpaired, two-tailed, confidence intervals: $95 \%$ ).

\section{RESULTS AND DISCUSSION}

Representative examples of cationic oligopeptides, listed in TABLE 1, were critically analysed and compared in well-defined in vitro assays. Our aim was to find good future peptide candidates for antimicrobial drug delivery. Cytotoxicity, haemolytic and antimicrobial activity of membrane-active peptides is often used to estimate their therapeutic applicability (Helmerhorst et al. 1999; Maher and McClean 2006). In this paper, we show that the calculated selectivity index is strongly dependent on the conditions (i.e. culturing media) of the in vitro assays. Therefore, systematic studies were performed to establish proper test conditions for accurate comparison. All 11 peptides were then tested on PBMC and MonoMac6 cells, against two bacterial strains (S. pneumoniae and M. tuberculosis) and on human erythrocytes in different incubation media. As positive control, Melittin was used which has strong lytic activity against microbes and human cells. OT20 was the negative control in this study. OT20 is a non membrane-active, receptor binding peptide, which represents comparable cationic character.

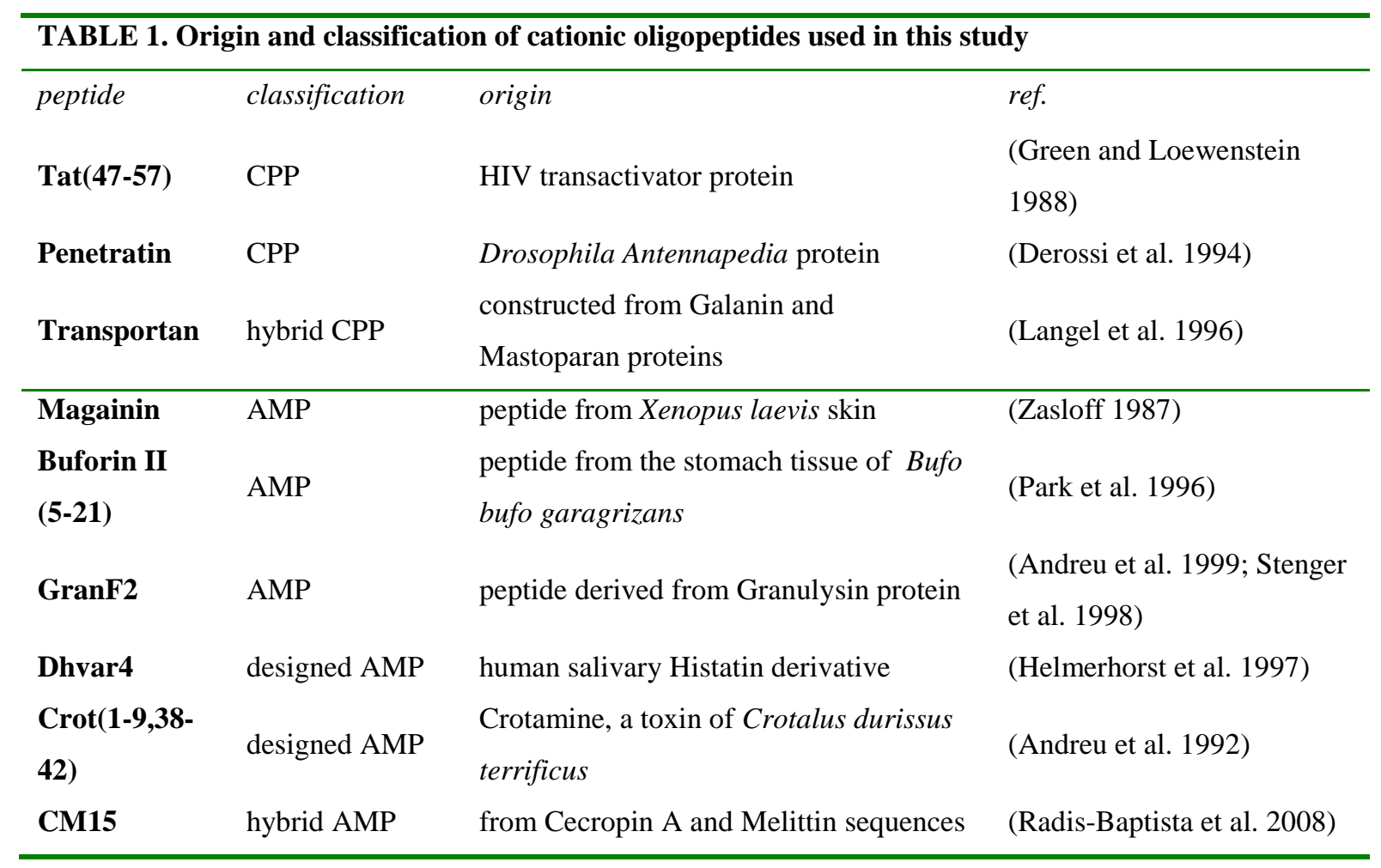




\begin{tabular}{llll}
\hline & $\begin{array}{l}\text { positive control } \\
\text { Melittin }\end{array}$ & & \\
& (strong lytic & venom of Apis mellifera & (Habermann 1972) \\
activity) & negative control & & \\
OT20 & tetramer derivative of tuftsin sequence & (Bai et al. 2008) \\
\hline
\end{tabular}

\subsection{Synthesis and Characteristics of Cationic Peptides}

Cationic peptides, listed in TABLE 2, were synthesized, purified and carefully characterized by analytical RP-HPLC, ESI MS and amino acid analysis.

Throughout experimental design it is important to note that the peptide content of a lyophilised material can vary according to the sequence and the used synthetic procedures. Generally, the content of residual salt and water, which are the main impurities in a lyophilized peptide, can be up to 40-50\%, especially in the case of high number of positively charged amino acids in the sequence. For more reliable comparison, precise determination of peptide content was evaluated by amino acid analysis. We found that the higher the average hydrophilicity $(H)$ was, the lower peptide content was measured. The average peptide content was $50 \%$, the lowest value was $41 \%$ for Tat(47-57) peptide (9+ charge in 11 amino acids), the highest was $58 \%$ for Magainin (4+ charge in 23 amino acids) (TABLE 2).

\begin{tabular}{|c|c|c|c|c|c|c|}
\hline peptide & sequence & $Z^{a}$ & $\begin{array}{l}M_{a v}{ }^{b} \\
\text { calcd / found }\end{array}$ & $\begin{array}{l}R_{t}^{c} \\
(\min )\end{array}$ & $H^{d}$ & $\begin{array}{l}\text { peptide } \\
\text { content }^{e} \\
\%\end{array}$ \\
\hline $\operatorname{Tat}(47-57)$ & YGRKKRRQRRR & $9+$ & $1558.9 / 1559.2$ & 15.5 & +2.0 & 41 \\
\hline Penetratin & RQIKIWFQNRRMKWKK & $8+$ & $2245.7 / 2245.6$ & 25.9 & +0.5 & 49 \\
\hline Transportan & AGYLLGKINLKALAALAKKIL & $5+$ & $2181.8 / 2181.9$ & $29.1 *$ & -0.3 & 56 \\
\hline Magainin & GIGKFLHSAKKFGKAFVGEIMNS & $4+$ & $2465.9 / 2466.0$ & 33.0 & -0.1 & 58 \\
\hline Buforin II (5-21) & RAGLQFPVGRVHRLLRK & $6+$ & $2002.4 / 2002.5$ & 26.8 & +0.2 & 52 \\
\hline GranF2 & VCRTGRSRWRDVCRNFMRRYQSR & $8+$ & $2988.5 / 2988.7$ & 27.7 & +0.6 & 45 \\
\hline Dhvar4 & KRLFKKLLFSLRKY & $7+$ & $1839.4 / 1839.6$ & 29.6 & +0.3 & 48 \\
\hline $\operatorname{Crot}(1-9,38-42)$ & YKQCHKKGGKKGSG & $6+$ & $1504.8 / 1504.9$ & 11.3 & +0.8 & 48 \\
\hline CM15 & KWKLFKKIGAVLKVL & $6+$ & $1770.3 / 1770.4$ & 32.0 & -0.1 & 52 \\
\hline Melittin & GIGAVLKVLTTGLPALISWIKRKRQQ & $6+$ & $2846.5 / 2846.6$ & 39.6 & -0.2 & 57 \\
\hline OT20 & TKPKGTKPKGTKPKGTKPKG & $9+$ & $2063.5 / 2063.5$ & 14.8 & +1.1 & 49 \\
\hline
\end{tabular}

$C$-terminus of the peptides was amidated. 
${ }^{a} Z$ : net charge at neutral pH. Calculated by the number of $(\mathrm{K}+\mathrm{R})-(\mathrm{E}+\mathrm{D})$. Positive charge at the $\mathrm{N}$-terminus increases $Z$ by 1 unit.

${ }^{b}$ Measured average molecular mass by Bruker Esquire 3000+ ESI-MS.

${ }^{c}$ Analytical RP-HPLC, gradient: 5\% B, 5 min; 5-60\% B, 35 min. * gradient: 10\% B, 5 min; 10-80\% B, 35 min.

${ }^{d} H$ : hydrophilicity is calculated from the average of hydrophilicity values of each amino acids (Hopp and Woods 1981).

${ }^{e}$ Peptide content was determined by amino acid analysis using freeze-dried final product.

\subsubsection{Counter-Ion Replacement}

After standard solid phase synthesis and purification, cationic peptides are often isolated as trifluoroacetate salts (Roux et al. 2008; Vemuri 2005). In the case of lysine and arginine rich peptide, the high amount of TFA can modify the biological and physicochemical properties (i.e. by modifying the conformation of the peptide, acidifying the media, and lowering the peptide content of the lyophilized powder). Therefore, we have changed the trifluoroacetate counterion for acetate (which is less acidic, less toxic and has lower molecular mass) using Amberlit IRA-400 anion-exchange resin. This process also removed the excess TFA. Anion-exchange rate was monitored by elemental analysis. The Fluorine content of the peptide after acetateexchange was decreased dramatically and the calculated exchange rate was up to $80 \%$ (F\% = 13.42 (unchanged peptide); 2.88 (acetate-exchanged)).

\subsubsection{Circular Dichroism Spectroscopic Investigation of the Secondary Structure of CM15 Peptide}

Far-UV CD spectra of peptides represent the summation of signals from the optically active n$\pi^{*}$ and $\pi-\pi^{*}$ transitions of the amide bonds (Toniolo et al. 2012). $\alpha$-Helical structures display a negative $\mathrm{n}-\pi^{*} \mathrm{CD}$ band at $\sim 220 \mathrm{~nm}$ and two, higher intensity negative-positive peaks at $\sim 207$ and $\sim 190 \mathrm{~nm}$, respectively. This couplet is attributable to chiral exciton interaction of the helically arranged amide chromophores. The $\beta$-sheet CD pattern consists of a negative $n-\pi^{*}$ band near $217 \mathrm{~nm}$ and two $\pi-\pi^{*}$ exciton components below $200 \mathrm{~nm}$. Unordered peptides and proteins show a strong negative peak centered in the 195-200 nm region and substantially weaker, positive or negative signals above $215 \mathrm{~nm}$. Taking these into consideration, the CD curve of CM15 measured in water $(\mathrm{pH} \sim 6)$ is characteristic to the dominant contribution of the unordered or random coil structure (FIGURE 1) (Pistolesi et al. 2007). In full concordance with this, quantitative analysis of the CD data yielded $62 \%$ random coil and $26 \% \beta$-sheet with no $\alpha$ helical content. Interestingly, a small fraction of type III $\beta$-turn (Reed and Reed 1997) was also 
required to achieve the best fit between the experimental and calculated data (FIGURE 1). In relation to water, the negative CD band is red shifted above $200 \mathrm{~nm}$ in buffer solution together with the development of a prominent shoulder above $215 \mathrm{~nm}$. According to the secondary structure estimation, these spectral changes can be associated to a $\beta$-turn $\rightarrow \alpha$-helix conformational conversion (FIGURE 1). These results suggest that the $\mathrm{pH}$ of the medium where CM15 acts, e.g., normal or acidic inflamed tissues, may provoke a slight, but significant modification of its secondary structure.

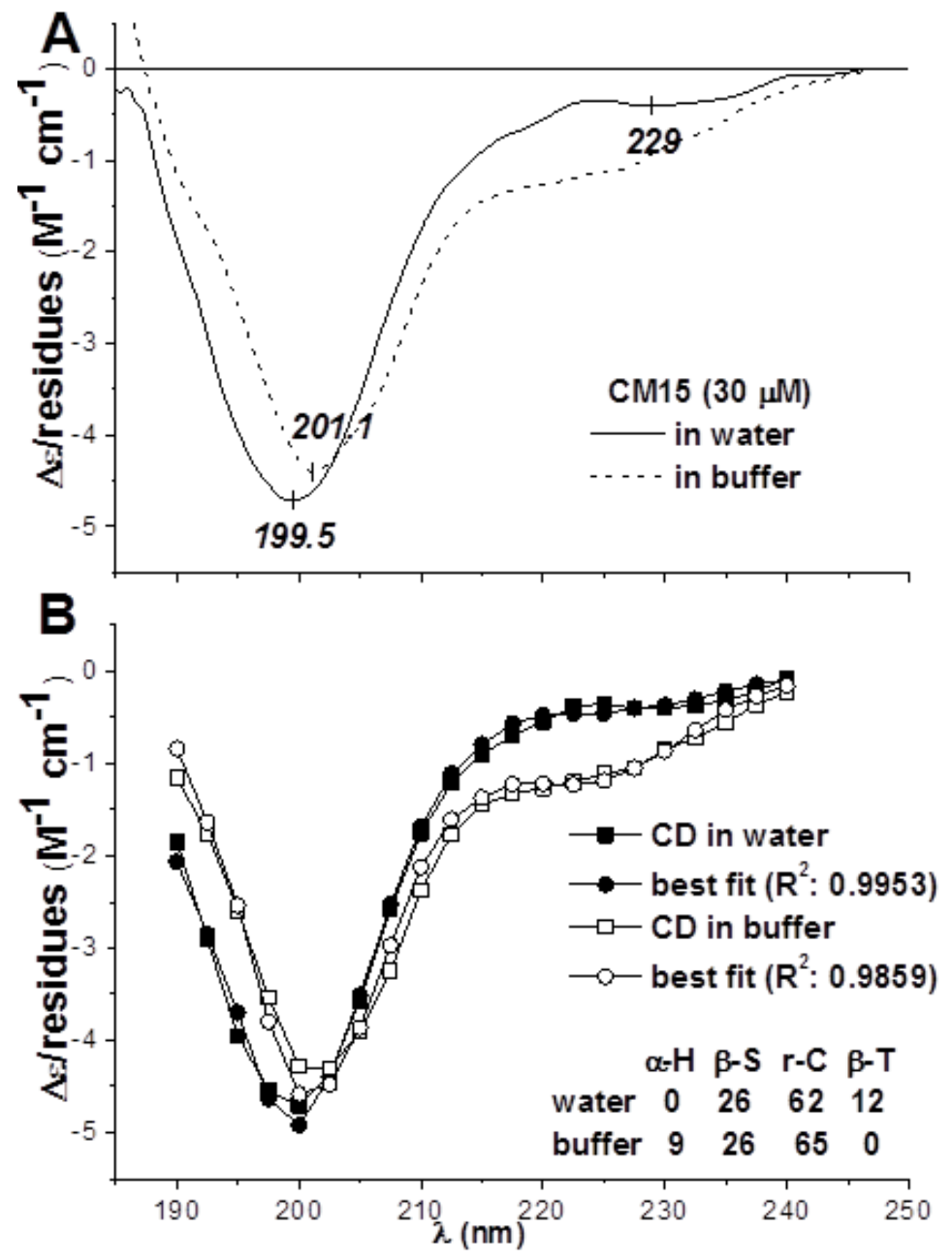

FIGURE 1. Far-UV CD spectra of CM15 peptide. CM15 peptide $(30 \mu \mathrm{M})$ was measured in deionized water ( $\left.\mathrm{pH} \sim 6,0.05 \mathrm{M} \mathrm{Na}_{2} \mathrm{SO} 4\right)$ and in $10 \mathrm{mM}$, $\mathrm{pH} 7.3$ potassium phosphate buffer $(0.05$ $\mathrm{M} \mathrm{Na}_{2} \mathrm{SO} 4$ ), panel A. Panel $\mathbf{B}$ represents the results of the curve-fitting procedure made by using the PEPFIT analysis program ( $\alpha$-H: $\alpha$-helix; $\beta$-S: $\beta$-sheet; r-C: random coil; $\beta$-T: type III $\beta$-turn). The inset shows the estimated secondary structure percentages of the peptide.

\subsection{Haemolytic Activity of Peptides: Effect of Experimental Conditions}

Published methods to determine haemolytic activity of cationic peptides often use different test conditions that can strongly influence the results. Therefore the effect of time, incubation buffer, 
concentration of RBC, identity of anticoagulant and counter-ion on haemolytic activity of cationic peptides was investigated. To establish proper test conditions CM15 peptide was chosen because of its average characteristics (charge and size) and medium haemolytic activity.

\subsubsection{Incubation Time and Media}

First, the time dependence of haemolysis evoked by cationic peptides was studied. Erythrocytes were incubated for $30 \mathrm{~min}, 2 \mathrm{hrs}, 4 \mathrm{hrs}$ or $24 \mathrm{hrs}$ with CM15 peptide. Half an hour was enough to reach the maximum haemolysis; no further haemoglobin release was detected (FIGURE 2 $\mathrm{A}, \mathrm{B})$. Comparing the means of the $\mathrm{HC}_{50}$ values no significant difference was observed $(\mathrm{P}=$ $0.4449)$.

In contrast, the type of incubation media strongly influenced the haemolytic activity of CM15 peptide. The resulted means of $\mathrm{HC}_{50}$ values showed significantly difference $(\mathrm{P}<0.0001)$ in the one-way ANOVA test. In the measurement of haemolysis, isotonic conditions are required to prevent erythrocytes from spontaneous lysis. Most commonly PBS and TRIS buffers are used in haemolytic assays however, for antimicrobial and cytotoxic assays these are considered to be high salt buffers (Helmerhorst et al. 1999). RPMI, DMEM and other cell culturing media contain amino acids, vitamins, glucose as well as additional supplementary components to be optimal for cultivation of certain cell types and are formulated to have the final osmolality in the range of 290 to $310 \mathrm{mOs} / \mathrm{kg}$. It was found that the haemolytic activity of CM15 peptide is significantly lower $(\mathrm{P}<0.0001)$ in PBS $(28.2 \pm 1.22 \mu \mathrm{M})$ than in cell culturing DMEM media (DMEM: $6.70 \pm 0.50 \mu \mathrm{M}$ ). Haemolysis in RPMI, DMEM and Bouillon broth were in the range of 6.70 to $15.32 \mu \mathrm{M}$ (FIGURE 2 C, D). For other cationic peptides, same results were found namely lower $\mathrm{HC}_{50}$ values were measured in PBS and Tris buffers than cell culturing media and broths (data not shown). 


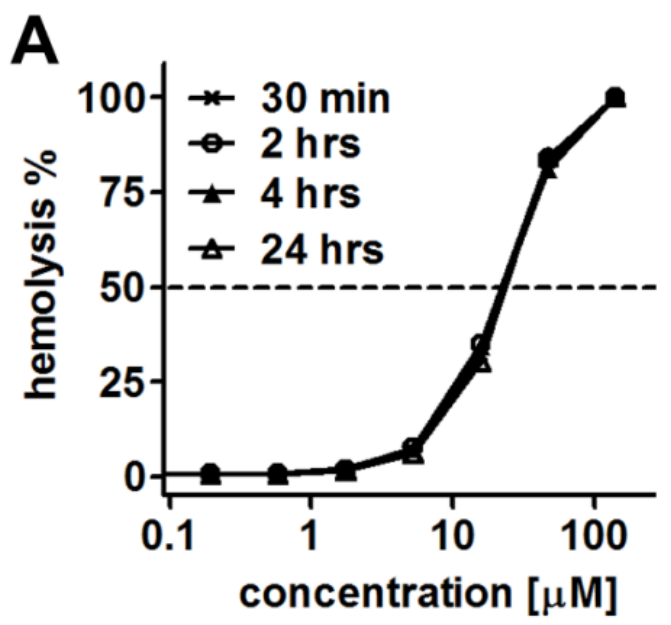

B
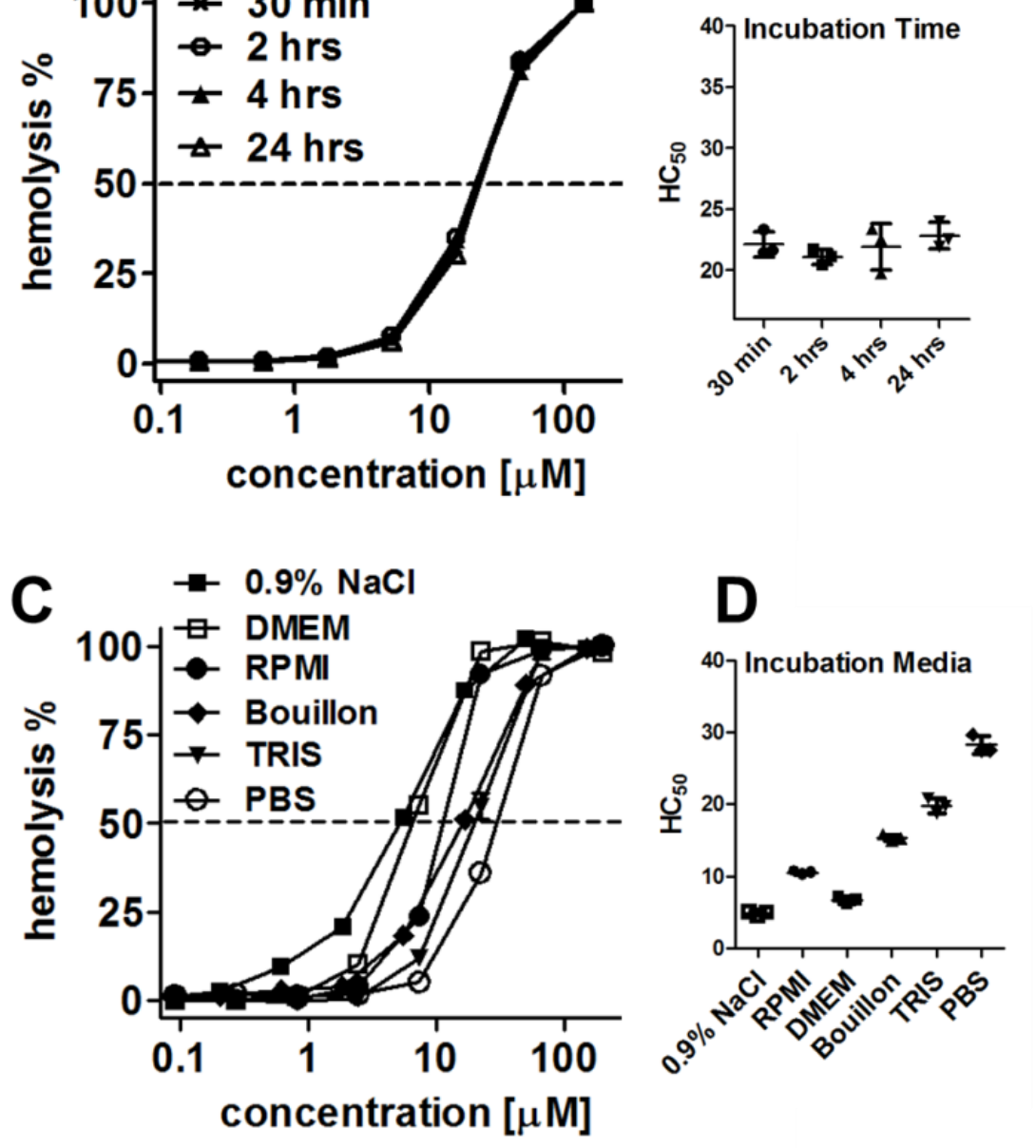

FIGURE 2. Effect of incubation time (A, B) and media (C, D) on the haemolytic activity of CM15 peptide. Human erythrocytes were treated with CM15 peptide at various concentrations using different experimental conditions and the haemolysis was determined by reading the absorbance of the supernatant at $\lambda=414 \mathrm{~nm}$. Haemolysis of the erythrocytes reached the maximum after 30 min treatment and no further haemoglobin release was measured. The haemolytic activity of CM15 peptide is strongly dependent on the used incubation buffer: in PBS significantly lower $\mathrm{HC}_{50}$ value was measured than in low ionic strength media or broth. (One-way ANOVA test, means are significantly different, $\mathrm{P}<0.0001)$.

In published methods there are differences even in the used wavelength at which the absorbance of the supernatant is measured. Percentage of haemolysis is calculated by dividing the absorbance measured for the peptide by the absorbance measured for the positive control (both values are corrected with the background). Therefore, the resulted \% haemolysis values are independent from the exact absorbance values. However, better results can be obtained if we measure at the maximum wavelength of the released haemoglobin. We found that the highest values can be measured if we monitor the absorbance at $414 \mathrm{~nm}$ or $405 \mathrm{~nm}$ (TABLE 3). 


\begin{tabular}{ccc}
\hline \multicolumn{2}{c}{ TABLE 3. Absorbance of the released haemoglobin at different wavelength } \\
\hline Wavelength & Absorbance $^{a}$ & $\pm S d^{a}$ \\
\hline $340 \mathrm{~nm}$ & 2.034 & 0.001 \\
$405 \mathrm{~nm}$ & 4.456 & 0.016 \\
$414 \mathrm{~nm}$ & 4.576 & 0.120 \\
$450 \mathrm{~nm}$ & 1.190 & 0.018 \\
$492 \mathrm{~nm}$ & 0.440 & 0.003 \\
$540 \mathrm{~nm}$ & 1.047 & 0.006 \\
\hline
\end{tabular}

Peptide treated erythrocytes were centrifuged and the supernatants were transferred to a flat-bottom microtiter plate. The absorbance was measured at various wavelengths using an ELISA plate reader.

${ }^{a}$ Means and standard deviations of two measurements.

\subsubsection{Concentration of Red Blood Cells, Presence of BSA, Anticoagulant and Counter Ion}

The percentage or cell number of RBC used in haemolytic assays differs in a wide concentration range. Therefore, to clarify the effect of RBC content, haemolysis of CM15 peptide was studied at $4 \%, 1 \%, 0.25 \%$ or $0.0625 \% \mathrm{RBC}$ concentration. No difference was measured $(\mathrm{P}=0.2862)$ for $4 \%, 1 \%, 0.25 \%$, while at $0.0625 \% \mathrm{RBC}$ concentration significantly lower $\mathrm{HC}_{50}$ value was measured $(\mathrm{P}=0.0004)($ FIGURE 3A)

Peptide and protein solutions are prone to loose activity as a result of aggregation, loss of original structure integrity and/or binding to the storage vessel. Therefore, it is widely recommended to dilute the samples in a buffer containing a stabilizer. The addition of bovine serum albumin (BSA) in a concentration of $1-10 \mathrm{mg} / \mathrm{ml}(0.1-1 \%)$ is a popular way to protect against such degradation and loss. To study the effect of BSA addition, CM15 peptide was diluted in a presence of $5 \mathrm{mg} / \mathrm{mL}(0.5 \%) \mathrm{BSA}$ and the haemolytic activity was tested. The results showed that the addition of BSA has no significant effect on the haemolytic activity of CM15 peptide $(\mathrm{P}=0.1018)$ (FIGURE 3B).

Although, published methods for analysis of haemolytic activity of cationic peptides mentioned different anticoagulant containing vacuum tubes for cupping, no systematic study was evaluated on the effect of anticoagulants. Therefore, most frequently used anticoagulant containing vacuum tubes were used to compare the effect of citrate, heparin and EDTA on the haemolytic activity of CM15 peptide. The results clearly showed that lysis of the red blood cells 
by CM15 cationic peptide was independent of the used anticoagulant $(\mathrm{P}=0.1210)$ (FIGURE $3 \mathrm{C})$.

In the case of lysine and arginine rich peptides, the high amount of TFA could alter the biological activity. Therefore, excess TFA and trifluoroacetate counter-ion was removed and changed to acetate counter-ion and the haemolytic activity of trifluoroacetate and acetate counter-ion containing CM15 peptide was assayed. No marked effect of counter-ion identity could be observed in case of CM15 peptide treated RBC $(\mathrm{P}=0.4106)$ (FIGURE 3D).
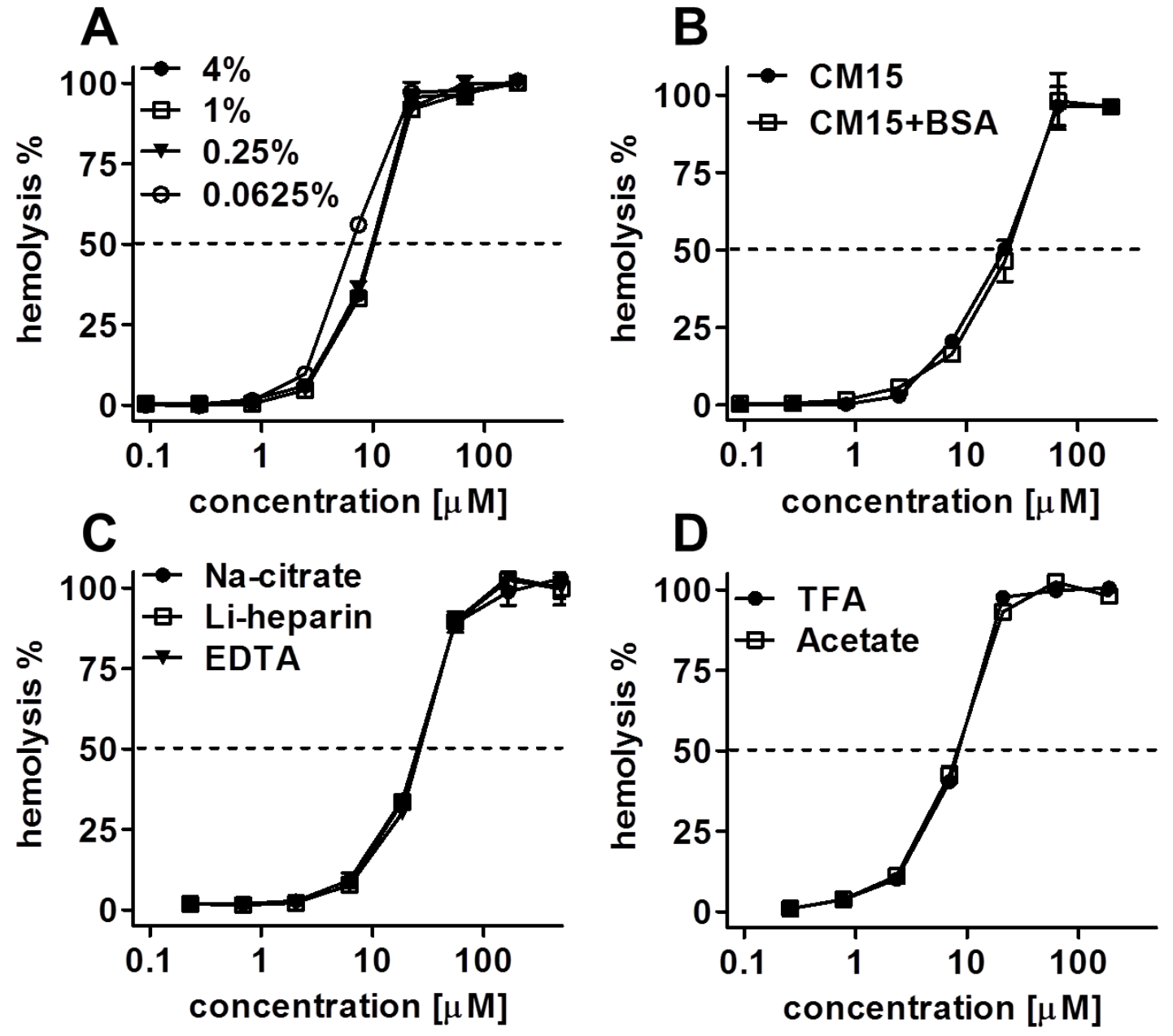

FIGURE 3. Effect of erythrocyte concentration (A) presence of bovine serum albumin (B), identity of anticoagulant $(C)$ and counter-ion (D) on the haemolytic activity of CM15 peptide. Human RBCs were treated with CM15 peptide using different test conditions and the haemolysis was determined by reading the absorbance of the supernatant at $\lambda=414 \mathrm{~nm}$. Haemoglobin release of $4 \%, 1 \%, 0.25 \%$ v/v RBCs evoked by the CM15 peptide showed no significant difference, while at $0.0625 \% \mathrm{RBC}$ concentration significantly lower $\mathrm{HC}_{50}$ value was measured (A). The addition of BSA to the test solution of CM15 does not alter its haemolytic activity (B). No significant differences 
in the resulted $\mathrm{HC}_{50}$ values were detected after using three different anticoagulants (C). Counter-ion replacement has no significant effect on the haemolytic activity of CM15 peptide.

\subsection{Cytotoxicity of Cationic Peptides}

Cytotoxicity of cationic peptides was studied on freshly prepared human PBMC in RPMI media (incubation time was $4 \mathrm{hrs}$ ) using MTT test. PBMC are isolated human cells which can be used to study general toxicity of a compound. The following order of cytotoxicity was found: (i) Melittin, Transportan, CM15 and Dhvar4 peptides have $\mathrm{IC}_{50}$ value lower than $50 \mu \mathrm{M}$; (ii) modest cytotoxicity $(50-300 \mu \mathrm{M})$ was measured for GranF2, Magainin and Penetratin; (iii) Tat(47-57), Buforin II, Crot(1-9,38-42) and OT20 peptides were not cytotoxic up to $300 \mu \mathrm{M}$ (TABLE 4).

When measuring the haemolytic activity of the peptides employing the same experimental conditions as for the cytotoxic assay (RPMI media, $4 \mathrm{hrs}$ of incubation), almost the same order of activity was found, namely the highest $\mathrm{HC}_{50}$ values were measured for Melittin, Transportan, CM15, and Transportan. Dhvar4 and GranF2 peptides were found to be cytotoxic to PBMC cells but not for red blood cells $\left(\mathrm{HC}_{50}>300 \mu \mathrm{M}\right)$.

\begin{tabular}{lcccccc}
\hline TABLE 4. Cytotoxic, haemolytic and antibacterial effect of cationic oligopeptides \\
\hline peptide & $I C_{50^{a}}{ }^{a}$ & $H C_{50}{ }^{b}$ & $M I C^{c}$ & $H C_{50}{ }^{d}$ & Selectivity & MTB MIC ${ }^{f}$ \\
& $(\mu M)$ & $(\mu M)$ & $(\mu M)$ & $(\mu M)$ & index $^{e}$ & $(\mu M)$ \\
\hline Tat(47-57) & $>300$ & $>300$ & 300 & $>300$ & 1 & $>300$ \\
Penetratin & $136 \pm 25.6$ & $>300$ & 1.2 & $>300$ & 250 & $>300$ \\
Transportan & $8.49 \pm 1.39$ & $38.0 \pm 3.79$ & 1.2 & $25.2 \pm 3.29$ & 21 & 80 \\
\hline Magainin & $132 \pm 23.8$ & $>300$ & 33 & $>300$ & 9 & $>300$ \\
Buforin II (5-21) & $>300$ & $>300$ & $>300$ & $>300$ & 1 & $>300$ \\
GranF2 & $80.1 \pm 18.5$ & $>300$ & 100 & $269 \pm 7.11$ & 3 & $>300$ \\
Dhvar4 & $38.6 \pm 5.76$ & $>300$ & 3.7 & $>300$ & 81 & $>300$ \\
Crot(1-9,38-42) & $>300$ & $>300$ & $>300$ & $>300$ & 1 & $>300$ \\
CM15 & $12.9 \pm 2.51$ & $18.9 \pm 1.71$ & 1.2 & $13.9 \pm 0.456$ & 12 & $>300$ \\
\hline Melittin & $0.941 \pm 0.237$ & $0.339 \pm 0.0854$ & 1.2 & $0.681 \pm 0.0542$ & 0.6 & $>300$ \\
OT20 & $>300$ & $>300$ & $>300$ & $>300$ & 1 & $>300$ \\
\hline${ }^{a}$ Mean IC 50 standard deviation. Cytotoxicity of peptides on human PBMC measured in RPMI media (4 hrs \\
incubation time).
\end{tabular}




\footnotetext{
${ }^{b}$ Mean $\mathrm{HC}_{50} \pm$ standard deviation. $\mathrm{HC}_{50}$ is a concentration at which $50 \%$ haemolysis of human $\mathrm{RBCs}$ occurs in RPMI (without phenol red) media (4 hrs incubation time).

${ }^{c}$ Minimal inhibitory concentration on Streptococcus pneumoniae strain determined in Bouillon broth (24 hrs of incubation).

${ }^{d}$ Mean $\mathrm{HC}_{50} \pm$ standard deviation determined in Bouillon broth with 24 hrs of incubation.

${ }^{e}$ Selectivity index was calculated from $\mathrm{HC}_{50} / \mathrm{MIC}$ (both measured in Bouillon broth)

${ }^{f}$ Minimal inhibitory concentration on Mycobacterium tuberculosis $\mathrm{H}_{37} \mathrm{Rv}$ strain determined in Sula media.

For samples, where $\mathrm{MIC}, \mathrm{IC}_{50}$ or $\mathrm{HC}_{50}$ was higher than $300 \mu \mathrm{M}$, a value of $300 \mu \mathrm{M}$ was assigned.
}

To estimate the cell-type dependence of cationic peptides four different human cells and cell lines were used. HepG2 human hepatocytes and SH-SY5Y human neuroblastoma cells are frequently used as hepatotoxicity and neurotoxicity model. MonoMac6 human monocytic cell line is a macrophage model which is suitable to bear intracellular bacteria. Cells were treated with Transportan at various peptide concentrations and the cytotoxicity was determined by MTT assay. Mean $\mathrm{IC}_{50}$ values showed significant difference $(\mathrm{P}<0.05)$ however, all IC50 were in the same concentration range: $4.70 \pm 1.02 \mu \mathrm{M}$ (MonoMac6), 6.78 $\pm 0.488 \mu \mathrm{M}$ (HepG2), $8.28 \pm 0.573 \mu \mathrm{M}$ (SH-SY5Y), 9.81 $\pm 0.473 \mu \mathrm{M}$ (PBMC) (FIGURE 4).

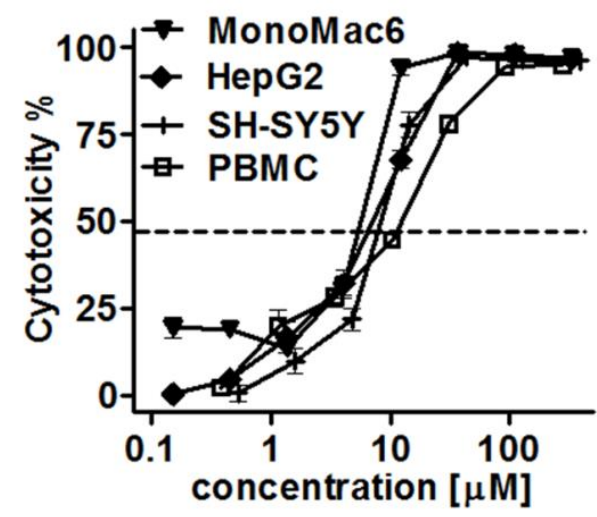

FIGURE 4. Cell-type dependence in the cytotoxicity assay. Freshly isolated PBMC, MonoMac6 human monocytes, HepG2 human hepatocytes and SH-SY5Y human neuroblastoma cells were treated with the peptide for 4 hrs at various concentrations and the cytotoxicity was determined by MTT assay. Comparing the $\mathrm{IC}_{50}$ values in one-way ANOVA test, significant difference was calculated however, the resulted IC50 values were at the same concentration range (between 4.70 $\mu \mathrm{M}$ and $9.81 \mu \mathrm{M})$. 
MonoMac6, which are adherent cells, were chosen to visualize the changes in the cell morphology caused by cationic peptides (FIGURE 5). Microscopic images of the peptide treated cells were captured using an Olympus CKX41 microscope. After treatment with Buforin II (5-21), Crot(1-9,38-42) and OT20 peptides, intact MonoMac6 cells were observed. Melittin, Transportan, CM15, Dhvar4 and GranF2 peptides caused severe damage on the cell membrane and provoked dramatic changes in the cell morphology. Penetratin, Magainin and Tat(47-57) peptides effected the cell membrane integrity just at the highest $(100 \mu \mathrm{M})$ concentration. These microscopic observations are in accordance with the result of the MTT assay.

FIGURE 5. Microscopic images of cationic peptide treated MonoMac6 cells. Cells were incubated

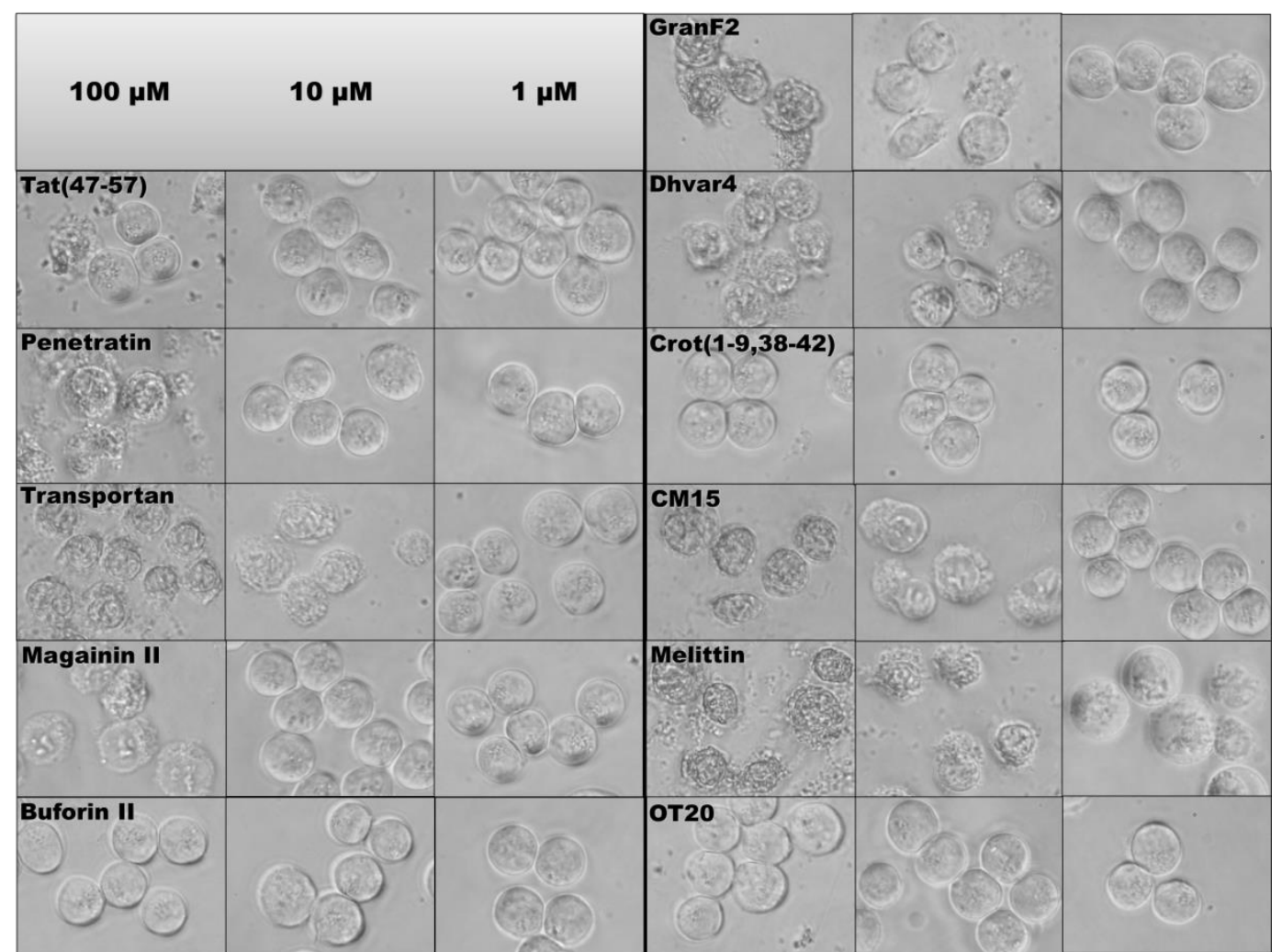

with the peptides for $4 \mathrm{hrs}$ at 1,10 and $100 \mu \mathrm{M}$ final concentration. Dramatic changes in the cell morphology were captured in the case of Melittin, Transportan, Dhvar4, CM15, and GranF2 peptides, which results are in accordance with the MTT assay.

\subsection{Internalisation of Cationic Peptides}

Cellular uptake of MonoMac6 human monocytic cells was measured by flow cytometry. For that purpose, peptides were labelled with 5(6)-carboxyfluorescein (Cf) and measured at 20, 10 and $5 \mu \mathrm{M}$ final concentrations (FIGURE 6). Based on the internalisation ability, three groups of peptides were created: (i) superior penetration was defined for peptides where the percentage of FITC positive cells was higher than $80 \%$ at $5 \mu \mathrm{M}$ concentration - Penetratin, Transportan, Dhvar4 and Melittin; (ii) good penetration for peptides where the percentage of FITC positive 
cells was higher than $50 \%$ at $10 \mu \mathrm{M}$ concentration - Tat, GranF2, CM15 and Buforin II; and (iii) modest penetration where the percentage of FITC positive cells was higher than $50 \%$ at 20 $\mu \mathrm{M}$ concentration - $\operatorname{Crot}(1-9,38-42)$, Magainin II and OT20. It is important to note, that peptides with superior penetration shows the highest cytotoxicity, especially Melittin, Transportan and Dhvar4. However, Penetratin, Tat and Buforin II peptides bear good internalisation property but low cytotoxicity.

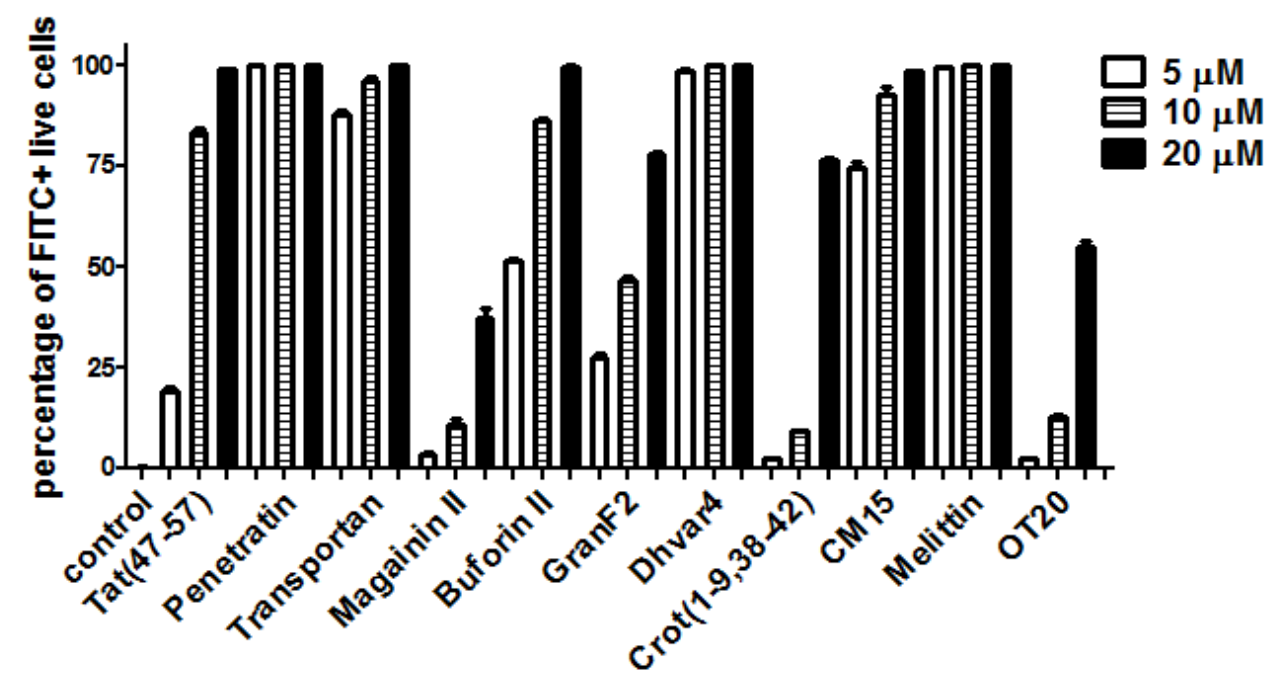

FIGURE 6. Internalisation of cationic peptides. Cellular uptake of MonoMac6 cells were measured by flow cytometry using 5(6)-carboxyfluorescein (Cf)-labelled peptides at 5, 10 and 20 $\mu \mathrm{M}$ concentration. The penetration ability was ranked according to the resulted percentage of FITC positive cells. Superior penetration: Penetratin, Transportan, Dhvar4 and Melittin; good penetrations: Tat, GranF2, CM15 and Buforin II; modest penetration: Crot(1-9,38-42), Magainin II and OT20.

\subsection{Antibacterial Activity against $S$. pneumonia.}

Antimicrobial efficacy of cationic peptides was measured against Streptococcus pneumoniae, a Gram-positive bacterium which is one of the most significant human pathogen (TABLE 4). Buforin II, Crot(1-9,38-42), Tat and OT20 control peptide were not effective against $S$. pneumonia. Magainin and GranF2 showed modest activity; CM15 and Dhvar4 peptides had potent antibacterial activity (less than $4 \mu \mathrm{M}$ ) just as Melittin. Interestingly, Penetratin and Transportan, which are classified as cell penetrating peptides, showed relevant antibacterial activity against Streptococcus pneumoniae. In the case of Penetratin, these findings are in accordance with a previous data, which suggested that the membrane induced $\alpha$-helical structure makes this peptide similar in activity to AMPs (Magzoub et al. 2002; Zhu and Shin 2009). 


\subsection{Transportan Is Effective against $M$. tuberculosis}

Antitubercular effect of all peptides was tested also on M. tuberculosis $\mathrm{H}_{37} \mathrm{Rv}$ strain. $M$. tuberculosis, the causative agent of tuberculosis, can survive in the host phagocytes for years or even decades and it is estimated that more than one-third of the world's population are infected with these pathogen (Lienhardt et al. 2012). Our results demonstrated that none of the peptides were effective against $M$. tuberculosis up to $300 \mu \mathrm{M}$ concentration, except Transportan. The MIC of Transportan peptide was $80 \mu \mathrm{M}$. No published data were found recently on the antitubercular effect of Transportan.

\subsection{In Vitro Selectivity of Cationic Peptides}

We found, that the haemolytic activity of the tested peptides is significantly lower in PBS than in RPMI or in Bouillon broth. Therefore, selectivity indices (given in TABLE 4) were calculated from the results of experiments using the same buffer and incubation time. Based on the comparison of antitubercular effect and haemolytic activity, most selective peptides (where the selectivity indices were higher than 20) were Penetratin, Dhvar4 and Transportan. Among these peptides, Penetratin showed the best selectivity, because the MIC value of Penetratin was 250 times lower than its $\mathrm{HC}_{50}$ value. Modest selectivity was found for Magainin II, GranF2 and CM15 peptides. Up to the highest concentration $(300 \mu \mathrm{M})$ no antibacterial and haemolytic activities were observed for Buforin II, Crot(1-9,38-42), Tat and OT20 peptides (TABLE 4). In the case of the positive control peptide Melittin, the MIC value was higher than the $\mathrm{HC}_{50}$ value.

\section{CONCLUSION}

Here we report the comparative analysis of cationic oligopeptides to identify potent antibacterial carriers for drug delivery. Peptide synthesis and purification was followed by accurate characterization of the product (molecular mass, retention time, peptide content). Haemolytic activity and cytotoxicity on isolated human blood cells and different cell lines have been systematically studied and compared to their penetrating ability and antibacterial activity against Streptococcus pneumoniae (pneumococcus) and Mycobacterium tuberculosis. We also clarified the role of the used media, incubation time, RBC concentration, addition of BSA, type of anticoagulant and counter-ion on the haemolytic activity of the peptides. We found, that the lytic activity of cationic peptides strongly depends on the used incubation media, which observation is in accordance with the results of the circular dichroism measurement. Therefore, 
it is uncertain whether the results of haemolytic assays, that are conducted in high salt buffers such as Tris od PBS, can be compared properly with the results of antibacterial assays, that are conducted in low ionic strength buffers or broths. Because of this observation, the same incubation media was applied both for the antibacterial assay and the haemolytic assay. We also found that the haemolytic activity of cationic peptides was almost independent from the other conditions like incubation time and type of anticoagulant. For a proper haemolytic assay, performed on human erythrocytes, at least $0.25 \% \mathrm{v} / \mathrm{v} \mathrm{RBC}$ concentration is required, which is equal to approximately $1-1.25 \times 10^{7}$ cells / $\mathrm{mL}$ (counting with the reference range of $\mathrm{RBC}$ of a male or female blood). When measuring the cytotoxicity of cationic peptides on different human cells and cell lines, almost the same order of activity was found than in the haemolytic assay.

As a summary of the performed assays we can conclude the following: (i) eight peptides showed superior or good penetration of which Tat, Penetratin, Dhvar4 and Buforin peptides have low haemolytic activity. Therefore, these peptides can be considered as good carriers for different drug molecules without causing severe damage on human cells. (ii) Transportan was found to be effective against $M$. tuberculosis $\mathrm{H}_{37} \mathrm{Rv}$ bacteria. However, Transportan was cytotoxic at this concentration range. (iii) Dhvar4 peptide showed superior antibacterial effect and penetration ability although, this peptide was cytotoxic to human PBMC but not to human erythrocytes. (iv) Penetratin was identified as promising antibacterial drug carrier with potent antibacterial effect (MIC lower than $1.2 \mu \mathrm{M}$ on pneumococcus) and superior penetration ability with low in vitro toxicity on human cells. Conjugation of an antibacterial drug to an antibacterial peptide is proposed to intensify the efficacy by multiple mode of action: including bacterial cell lysis, inhibiting bacterial enzymes, interacting directly with the cytoplasmic membrane and inhibiting intracellular targets. In addition, the consequence of the multiple mechanism of action is the low potential to induce microbial resistance. Therefore, Penetratin and its analogues with remarkable antibacterial activity and high selectivity will be further investigated as drug delivery systems for antibacterial agents. 


\section{COMPLIANCE WITH ETHICAL STANDARDS}

Conflict of Interest: The authors declare that they have no conflict of interest.

Funding: This study was funded by the Hungarian Research Fund (115431 and 104275) and by the János Bolyai Research Scholarship of the Hungarian Academy of Sciences.

Informed consent: The authors confirm that this work is new and original and not under consideration elsewhere. Our institute, the MTA-ELTE Research Group of Peptide Chemistry, Hungarian Academy of Sciences, and all authors have agreed to the submission of this manuscript.

Research involving human participants and/or animals: This article does not contain any studies with human participants or animals performed by any of the authors. 


\section{REFERENCES}

Amon MA, Ali M, Bender V, Hall K, Aguilar MI, Aldrich-Wright J, Manolios N (2008) Kinetic and conformational properties of a novel T-cell antigen receptor transmembrane peptide in model membranes. J Pept Sci 14:714-724. doi:10.1002/psc.987

Andreu D, Carreno C, Linde C, Boman HG, Andersson M (1999) Identification of an antimycobacterial domain in NK-lysin and granulysin. Biochem J 344:845-849. doi:10.1042/bj3440845

Andreu D, Ubach J, Boman A, Wahlin B, Wade D, Merrifield RB, Boman HG (1992) Shortened cecropin A-melittin hybrids. Significant size reduction retains potent antibiotic activity. FEBS Lett 296:190-194. doi:10.1016/0014-5793(92)80377-S

Bai KB, Lang O, Orban E, Szabo R, Kohidai L, Hudecz F, Mezo G (2008) Design, synthesis, and in vitro activity of novel drug delivery systems containing tuftsin derivatives and methotrexate. Bioconjug Chem 19:2260-2269. doi:10.1021/bc800115w

Baranyai $\mathrm{Z}$ et al. (2015) Combating highly resistant emerging pathogen Mycobacterium abscessus and Mycobacterium tuberculosis with novel salicylanilide esters and carbamates. Eur J Med Chem 101:692-704. doi:10.1016/j.ejmech.2015.07.001

Brown ED, Wright GD (2016) Antibacterial drug discovery in the resistance era. Nature 529:336-343. doi:10.1038/nature17042

Chen Y, Mant CT, Farmer SW, Hancock RE, Vasil ML, Hodges RS (2005) Rational design of alpha-helical antimicrobial peptides with enhanced activities and specificity/therapeutic index. J Biol Chem 280:12316-12329. doi:10.1074/jbc.M413406200

Chongsiriwatana NP et al. (2008) Peptoids that mimic the structure, function, and mechanism of helical antimicrobial peptides. PNAS 105:2794-2799. doi:10.1073/pnas.0708254105

Dathe M, Nikolenko H, Meyer J, Beyermann M, Bienert M (2001) Optimization of the antimicrobial activity of magainin peptides by modification of charge. Febs Lett 501:146-150. doi:10.1016/S0014-5793(01)02648-5 
Dathe M et al. (1996) Peptide helicity and membrane surface charge modulate the balance of electrostatic and hydrophobic interactions with lipid bilayers and biological membranes. Biochemistry 35:12612-12622. doi:10.1021/bi960835f

Davanco MG et al. (2014) Evaluation of Antimalarial Activity and Toxicity of a New Primaquine Prodrug. Plos One 9 doi:10.1371/journal.pone.0105217

Dennison SR, Phoenix DA (2014) Susceptibility of sheep, human, and pig erythrocytes to haemolysis by the antimicrobial peptide Modelin 5. Eur Biophys J 43:423-432. doi:10.1007/s00249-014-0974-9

Derossi D, Joliot AH, Chassaing G, Prochiantz A (1994) The third helix of the Antennapedia homeodomain translocates through biological membranes. J Biol Chem 269:1044410450. doi:PMID:8144628

El-Andaloussi S, Holm T, Langel U (2005) Cell-penetrating peptides: mechanisms and applications. Curr Pharm Des 11:3597-3611. doi:10.2174/138161205774580796

Green M, Loewenstein PM (1988) Autonomous functional domains of chemically synthesized human immunodeficiency virus tat trans-activator protein. Cell 55:1179-1188. doi:10.1016/0092-8674(88)90262-0

Habermann E (1972) Bee and wasp venoms. Science 177:314-322. doi:10.1126/science.177.4046.314

Helmerhorst EJ, Reijnders IM, van't Hof W, Veerman ECI, Amerongen AVN (1999) A critical comparison of the hemolytic and fungicidal activities of cationic antimicrobial peptides. Febs Letters 449:105-110. doi:10.1016/S0014-5793(99)00411-1

Helmerhorst EJ, Van't Hof W, Veerman EC, Simoons-Smit I, Amerongen AVN (1997) Synthetic histatin analogues with broad-spectrum antimicrobial activity. Biochemistry 326:39-45. doi:WOS:A1997XR05800005

Herbel V, Wink M (2016) Mode of action and membrane specificity of the antimicrobial peptide snakin-2. Peerj 4 doi:10.7717/peerj.1987 
Hollmann A et al. (2016) Role of amphipathicity and hydrophobicity in the balance between hemolysis and peptide-membrane interactions of three related antimicrobial peptides. Colloids Surf B Biointerfaces 141:528-536. doi:10.1016/j.colsurfb.2016.02.003

Hopp TP, Woods KR (1981) Prediction of protein antigenic determinants from amino acid sequences. PNAS 78:3824-3828. doi:PMID: 6167991

Horvati K et al. (2012) Enhanced Cellular Uptake of a New, in Silico Identified Antitubercular Candidate by Peptide Conjugation. Bioconjug Chem doi:10.1021/bc200221t

Horvati K et al. (2015) Antimycobacterial activity of peptide conjugate of pyridopyrimidine derivative against Mycobacterium tuberculosis in a series of in vitro and in vivo models. Tuberculosis 95:S207-S211. doi:10.1016/j.tube.2015.02.026

Hudecz F, Banoczi Z, Csik G (2005) Medium-sized peptides as built in carriers for biologically active compounds. Med Res Rev 25:679-736. doi:10.1002/med.20034

Kaushik NK, Sharma J, Sahal D (2012) Anti-plasmodial action of de novo-designed, cationic, lysine-branched, amphipathic, helical peptides. Malaria J 11:256. doi:10.1186/14752875-11-256

Kobayashi S, Takeshima K, Park CB, Kim SC, Matsuzaki K (2000) Interactions of the novel antimicrobial peptide buforin 2 with lipid bilayers: Proline as a translocation promoting factor. Biochemistry 39:8648-8654. doi:10.1021/bi0004549

Langel U, Pooga M, Kairane C, Zilmer M, Bartfai T (1996) A galanin-mastoparan chimeric peptide activates the $\mathrm{Na}+\mathrm{K}(+)$-ATPase and reverses its inhibition by ouabain. Regul Pept 62:47-52. doi:10.1016/0167-0115(96)00002-X

Lee J, Lee DG (2008) Structure-antimicrobial activity relationship between pleurocidin and its enantiomer. Exp Mol Med 40:370-376. doi:10.3858/emm.2008.40.4.370

Li Q et al. (2005) Hemolysis of erythrocytes by granulysin-derived peptides but not by granulysin. Antimicrob Agents Ch 49:388-397. doi:10.1128/AAC.49.1.388-397.2005

Lienhardt C, Glaziou P, Uplekar M, Lonnroth K, Getahun H, Raviglione M (2012) Global tuberculosis control: lessons learnt and future prospects. Nat Rev Microbiol 10:407-416. doi:10.1038/nrmicro2797 
Liu Y, Peterson DA, Kimura H, Schubert D (1997) Mechanism of cellular 3-(4,5dimethylthiazol-2-yl)-2,5-diphenyltetrazolium bromide (MTT) reduction. J Neurochem 69:581-593. doi:10.1046/j.1471-4159.1997.69020581.x

Magzoub M, Eriksson LE, Graslund A (2002) Conformational states of the cell-penetrating peptide penetratin when interacting with phospholipid vesicles: effects of surface charge and peptide concentration. Biochim Biophys Acta 1563:53-63. doi:10.1016/S00052736(02)00373-5

Maher S, McClean S (2006) Investigation of the cytotoxicity of eukaryotic and prokaryotic antimicrobial peptides in intestinal epithelial cells in vitro. Biochem Pharmacol 71:1289-1298. doi:10.1016/j.bcp.2006.01.012

Marr AK, Gooderham WJ, Hancock RE (2006) Antibacterial peptides for therapeutic use: obstacles and realistic outlook. Curr Opin Pharmacol 6:468-472. doi:10.1016/j.coph.2006.04.006

Mezo G et al. (2004) Synthesis, conformation, and immunoreactivity of new carrier molecules based on repeated tuftsin-like sequence. Biopolymers 73:645-656. doi:10.1002/bip.20024

Mojsoska B, Zuckermann RN, Jenssen H (2015) Structure-activity relationship study of novel peptoids that mimic the structure of antimicrobial peptides. Antimicrob Agents Chemother 59:4112-4120. doi:10.1128/AAC.00237-15

Morris MC, Deshayes S, Heitz F, Divita G (2008) Cell-penetrating peptides: from molecular mechanisms to therapeutics. Biol Cell 100:201-217. doi:10.1042/BC20070116

Mosmann T (1983) Rapid colorimetric assay for cellular growth and survival: application to proliferation and cytotoxicity assays. J Immunol Methods 65:55-63. doi:10.1016/00221759(83)90303-4

Park CB, Kim MS, Kim SC (1996) A novel antimicrobial peptide from Bufo bufo gargarizans. Biochem Biophys Res Commun 218:408-413. doi:10.1006/bbrc.1996.0071 
Pistolesi S, Pogni R, Feix JB (2007) Membrane insertion and bilayer perturbation by antimicrobial peptide CM15. Biophysical J 93:1651-1660. doi:10.1529/biophysj.107.104034

Portlock SH, Clague MJ, Cherry RJ (1990) Leakage of internal markers from erythrocytes and lipid vesicles induced by melittin, gramicidin $S$ and alamethicin: a comparative study. Biochim Biophys Acta 1030:1-10. doi:10.1016/0005-2736(90)90231-C

Radis-Baptista G, de la Torre BG, Andreu D (2008) A novel cell-penetrating peptide sequence derived by structural minimization of a snake toxin exhibits preferential nucleolar localization. J Med Chem 51:7041-7044. doi:10.1021/jm8009475

Raghuraman H, Chattopadhyay A (2006) Effect of ionic strength on folding and aggregation of the hemolytic peptide melittin in solution. Biopolymers 83:111-121. doi:10.1002/bip.20536

Raghuraman H, Ganguly S, Chattopadhyay A (2006) Effect of ionic strength on the organization and dynamics of membrane-bound melittin. Biophys Chem 124:115-124. doi:10.1016/j.bpc.2006.06.011

Reddy KV, Yedery RD, Aranha C (2004) Antimicrobial peptides: premises and promises. Int J Antimicrob Agents 24:536-547. doi:10.1016/j.ijantimicag.2004.09.005

Reed J, Reed TA (1997) A set of constructed type spectra for the practical estimation of peptide secondary structure from circular dichroism. Anal Biochem 254:36-40. doi:10.1006/abio.1997.2355

Rogers RN, Yasuda SK (1959) Rapid microdetermination of Fluorine in organic compounds. Anal Chem 31:616-617. doi:10.1021/ac50164a049

Roux S, Zekri E, Rousseau B, Paternostre M, Cintrat JC, Fay N (2008) Elimination and exchange of trifluoroacetate counter-ion from cationic peptides: a critical evaluation of different approaches. J Pept Sci 14:354-359. doi:10.1002/psc.951

Saberwal G, Nagaraj R (1994) Cell-lytic and antibacterial peptides that act by perturbing the barrier function of membranes: facets of their conformational features, structure- 
function correlations and membrane-perturbing abilities. Biochim Biophys Acta 1197:109-131. doi:10.1016/0304-4157(94)90002-7

Slater TF, Sawyer B, Straeuli U (1963) Studies on Succinate-Tetrazolium Reductase Systems. Iii. Points of Coupling of Four Different Tetrazolium Salts. Biochim Biophys Acta 77:383-393. doi:10.1016/0006-3002(63)90513-4

Song YM et al. (2005) Cell selectivity and mechanism of action of antimicrobial model peptides containing peptoid residues. Biochemistry 44:12094-12106. doi:10.1021/bi050765p

Stenger S et al. (1998) An antimicrobial activity of cytolytic T cells mediated by granulysin. Science 282:121-125. doi:10.1126/science.282.5386.121

Sula L (1963) Who Co-Operative Studies on a Simple Culture Technique for the Isolation of Mycobacteria. 1. Preparation, Lyophilization and Reconstitution of a Simple SemiSynthetic Concentrated Liquid Medium; Culture Technique; Growth Pattern of Different Mycobacteria. Bull World Health Organ 29:589-606. doi:PMCID: PMC2555071

Sula L, Sundaresan TK (1963) Who Co-Operative Studies on a Simple Culture Technique for the Isolation of Mycobacteria. 2. Comparison of the Efficacy of Lyophilized Liquid Medium with That of Loewenstein-Jensen (L-J) Medium. Bull World Health Organ 29:607-625. doi:PMCID: 2555071

Toniolo C, Formaggio F, Woody RW (2012) Electronic Circular Dichroism of Peptides. In: Berova N, Polavarapu PL, Nakanishi K, Woody RW (eds) Comprehensive Chiroptical Spectroscopy: Applications in Stereochemical Analysis of Synthetic Compounds, Natural Products, and Biomolecules, vol 2. pp 499-544. doi:10.1002/9781118120392

Vemuri S (2005) Comparison of assays for determination of peptide content for lyophilized thymalfasin. J Pept Res 65:433-439. doi:10.1111/j.1399-3011.2005.00225.x

Vinsova J et al. (2006) Synthesis and antimicrobial evaluation of new 2-substituted 5,7-di-tertbutylbenzoxazoles. Bioorg Med Chem 14:5850-5865. doi:10.1016/j.bmc.2006.05.030

Vives E, Schmidt J, Pelegrin A (2008) Cell-penetrating and cell-targeting peptides in drug delivery. Biochim Biophys Acta 1786:126-138. doi:10.1016/j.bbcan.2008.03.001 
Wu S et al. (2014) Genomic and functional characterization of three new venom peptides from the scorpion Heterometrus spinifer. Peptides 53:30-41. doi:10.1016/j.peptides.2013.12.012

Yang QZ, Wang C, Lang L, Zhou Y, Wang H, Shang DJ (2013) Design of potent, non-toxic anticancer peptides based on the structure of the antimicrobial peptide, temporin-1CEa. Arch Pharm Res 36:1302-1310. doi:10.1007/s12272-013-0112-8

Yeaman MR, Yount NY (2003) Mechanisms of antimicrobial peptide action and resistance. Pharmacol Rev 55:27-55. doi:10.1124/pr.55.1.2

Yeung AT, Gellatly SL, Hancock RE (2011) Multifunctional cationic host defence peptides and their clinical applications. Cell Mol Life Sci 68:2161-2176. doi:10.1007/s00018-0110710-x

Zasloff M (1987) Magainins, a class of antimicrobial peptides from Xenopus skin: isolation, characterization of two active forms, and partial cDNA sequence of a precursor. Proc Natl Acad Sci U S A 84:5449-5453. doi:10.1073/pnas.84.15.5449

Zeitler B, Diaz AH, Dangel A, Thellmann M, Meyer H, Sattler M, Lindermayr C (2013) DeNovo Design of Antimicrobial Peptides for Plant Protection. Plos One 8 doi:10.1371/journal.pone.0071687

Zhu WL, Shin SY (2009) Antimicrobial and cytolytic activities and plausible mode of bactericidal action of the cell penetrating peptide penetratin and its lys-linked twostranded peptide. Chem Biol Drug Des 73:209-215. doi:10.1111/j.17470285.2008.00769.x 